\title{
Status of Black Cumin (Nigella Sativa L.) Research and Production in Ethiopia; A Review
}

\author{
Zigyalew Gashaw* \\ Injibara University College of Agriculture, Food and Climate Science, Ethiopia
}

*Corresponding Author: Zigyalew Gashaw, Injibara University College of Agriculture, Food and Climate Science, Ethiopia

\begin{abstract}
Black cumin (Nigella sativa L.) in family Rannunculaceae is one of the most important earliest cultivated plants in history of spices with worldwide distribution. The miracle seed has been used by millions of people to treat various ailments for centuries in different parts of world as it contains essential macro and micronutrients which play vital roles as structural and functional components of metaloproteins and enzymes in the living cells. It is produced in most parts of Ethiopia and its uses are diverse from spices and medicinal aspects. The country generated 1.55 million USD in 2009/10 crop season from export of 801 MT cumin seeds in addition to huge domestic consumption. Since black cumin is high value spice and medicinal crop higher attention were given by national spice research sector. Ethiopia is one of the centers of diversity of black cumin. From entries of black cumin local cultivars grown 84 accessions have been collected by IBC from potential production areas/agro ecologies and under maintenance. Various reports indicated there is significant variability among entries in their vegetative performance, yield, and yield components and their reaction to pests. So far, improved varieties; Darbera, Dershaye, Eden have been released for users. However, with huge potential (production and export), the production and productivity of this spice crop remained very low due to a number of challenges; shortage of improved variety, traditional production, less awareness and inferior attention on its importance, lack of processing factory and market. Updated information on current status of black cumin production, productivity, market, potentials and prospects in the country is also lacking. This helps to give updated image for producers and policy makers and to give possible direction of black cumin revitalization. Therefore, this paper reviews the research activities conducted and achievements in different disciplines so far, the status of current production and the challenges and future prospects in the country.
\end{abstract}

\section{INTRODUCTION}

Black cumin (Nigella sativa) is one of the most important spices and medicinal crop; it is the miracle herb of the century, (Goreja, 2003). It belongs to the large family Ranunculaceae, containing about 70 genera and at least 3000 species. The genus Nigella contains about 14 species of annual herbs (Weiss, 2002). Nigella sativa (diploid, $2 \mathrm{n}=12$ ) is an erect annual herb considered as an important for both oil and bioactive compounds because its constituents have unique chemical properties and may augment the supply of edible oils or production of biodiesel (Ramadan and Morsel, 2003; Iqbal et al., 2010). Black cumin is native to the Mediterranean region through West Asia to northern India and has long been domesticated.

It is a minor seed spice cultivated from Morocco to Northern India; in sub- Saharan Africa, particularly Niger and eastern Africa, especially Ethiopia. The fact that black cumin found in different countries is proved by its different names in various countries; black cumin has different names given in different regions different names like "Tikur azmud" asmut (Amharic), Gurraacha habasudu, abosuda, nugi guracha, gurati, gurra (Gallinia), aaf (Kefa), awosetta (Tigrinia) (Jansen, 1981) which is an annual flowering plant grown as a rain fed crop within 1500 to 2400 masl on heavy black soils in similar ecological conditions to teff, chick pea and lentil (Girma et al., 2015 ).

Black cumin seeds have been used to successfully keep people's health beginning ancient times. Which is testified in both religious and scientific evidences; the actual importance of $N$. sativa to the Muslims came from the holy saying of the Prophet Mohammed, black seed is the medicine for every disease except death (Ghaznavi, 1991). And also cumin in the bible mentioned both the old and New Testament where it is saied that cumin was used as a currency to pay tithe to the ancient Rome and Greece priests (Azeez, 2008). Black cumin contains essential macro and micronutrients which play vital roles as 
structural and functional components of metalloproteins and enzymes in the living cells (Ansari et al., 2004) that is why it can give us medicinal value.

Recently, industry facilities based on the evaluation of medicinal and aromatic plants in which included the black cumin. Industrialists emphasize that the demand to fixed oil of black cumin is much and so, the necessity of increasing local production for the supply of raw material (Yilmaz, 2008). For this reason, black cumin is a plant having potential to be produced in producing countries in the future like Ethiopia.

As sited yimam, 2015. In Ethiopia black cumin is the second cash crop exported next to ginger, (The spice sector strategy committee, 2010). The country exported at a value of 1.18 USD kgG1 but imported 5.80 USD kgG1. This shows that there is a wide room for black cumin production and Ethiopia has about $12 \%$ share in the world market. However, $99 \%$ of the produce consumed locally. Due to the increased demand of black cumin seed for local consumption and other importance's, such as oil and oleoresin for medicinal purposes in the world and also in Ethiopia, its export market, its potentiality in crop diversification, income generation and its importance to reduce the risk of crop failure and others made black cumin as a best alternative crop under Ethiopian smaller land holdings.

In Ethiopia production is normally by subsistence farmers, total area under spices production is estimated to be 90,959 ha. Of this area, 9, 204 ha of land were covered by Ethiopian caraway and black Cumin in 2003 with production of 5,887 tons (MoARD, 2003). But in major black cumin producing regions of SNNP, Oromia and Amhara regions 42,012.00 quintal black cumin produced with in 13,672.52 ha of land, (Ministry of Trade and Industry, 2010). According to MoA produced in the year 2012, 9533 ton/cumin in 5336 ha of land. And then according to Ethiopian Investment Agency, (2015) annual production of black cumin increased rapidly from the previous low production level to 18000 metric ton seed produced 2014/15 production season.

From the vast majority of Ethiopia's black cumin exports go to Arab countries, which, together with other predominantly Muslim countries, accounted in 2008 for some $98 \%$ of national exports. Sudan overtook Saudi Arabia as the main export destination in 2007 and by 2008 it accounted for almost one half of all official exports. It is uncertain how reliable this market is and whether exports can be maintained at current levels. Value-adding to cumin in Ethiopia is low, with all exports being made in the form of whole grain (Ethiopian Investment Agency, 2010; Ostlund, 2002; Yazachew, 2011).

However, the share of spices export in total export earnings of Ethiopia has in general remained negligible $(<1 \%)$ from the total export earnings. Ethiopia's export of spices for the recently completed $2009 / 10$ shows that ginger, turmeric and cumin are the leading export commodities with these cumin shares $8.4 \%$. In terms of volume, the export of cumin accounted $(7.9 \%)$ and ranked $3^{\text {rd }}$. In value terms, ginger claimed a higher share of $62 \%$ of total spice export, followed by cumin seed (13.7\%). In 2009/10, export of cumin was $801 \mathrm{MT}$ valued at 1.55 million USD. Based on the trade statistics descriptive information, white cumin (WC) is a negligible export with a share of $2.4 \%$ in volume and $0.98 \%$ in value terms of total cumin export from Ethiopia in 2009/10 when we see its volume Black cumin accounts $781,292.50 \mathrm{~kg}$ while White Cumin 19,336.00 kg and also its value of BC, USD 1,539,859.00 while WC, 15,195.20 (yimer, 2010).

Since black cumin is found in different parts of Ethiopia at various altitude ranges it shows there is a potential to grow black cumin in wide agro ecology and also preferred for the existence of genetic diversity of black cumin species. However, there is no enough information about even for 84 conserved accessions of 34, 24, 10, 9 and 7 accessions collected from Oromia, Amhara, Benshangul Gumuz, Tigray and South Nation's Nationality Peoples Regions respectively, (Birhanu, 2015); about their genetic diversity of these herbs has been generated for the Ethiopian black cumin population. One of the important factors restricting their large-scale production and development of better varieties is that very little information is available about their genetic diversity, inter and intra-specific variability and genetic relationships among these species.

Despite the country's favorable environmental condition for its production and its importance, black cumin cropping system, as a sole crop has not been practiced mostly. In addition, recommended varieties were not sufficiently identified and introduced to the farmers for all growing areas, little attention has been given to improve its production and productivity and hence, it remained an underutilized crop. 
Therefore, the aim of this paper is to review current status of black cumin to give updated image for producers and policy makers and to give possible direction of the cumin revitalization. And also; to give summary of reviews, the research activities conducted and achievements in different disciplines so far, the status of current production, research achievements done and the challenges and future prospects in the country to put clear image and to give research direction on status of black cumin production in Ethiopia.

\section{Biology OF BLACK CUMIN}

\subsection{Morphology of Black Cumin}

Nigella sativa is an annual flowering plant grows at $20-90 \mathrm{~cm}$ tall, with finely divided leaves; the flowers are white, yellow, pink, pale blue or pale purple color, with 5-10 petals. The fruit is a large and inflated capsule consists of 3-7 united follicles, each containing several seeds (Goreja, 2003).
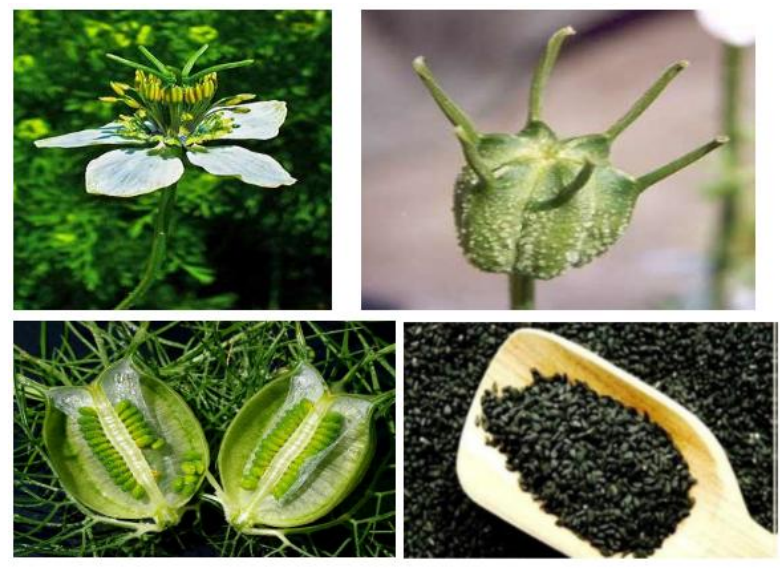

Seeds are small dicotyledonous, trigonus, angular, tubercular, black externally and white inside, odor slightly aromatic and taste bitter (Warrier et al., 2004). Germination is epigeal and takes 10-15 days, in temperate climates black cumin starts flowering about 100 days after sowing and seed reaches maturity 50 days later. In warmer climates, flowering may start 8-10 weeks after germination. Flowering is protandrous and pollination is believed to be mainly by insects. The flowering starts from the tip and progresses down to the bottom, (Miheretu, 2016).

In older flowers the stigmas bend down and self-pollination may occur, $N$. sativa responds favorably to fertilizers. Plants are more hairy with smaller flowers and more tuberculate fruits. Propagation and planting of N.sativa can easily by seed. Seed is broadcast as seedlings are too fragile for transplanting, but seed may also be sown in peat blocks. A row spacing of $15-40 \mathrm{~cm}$ is common. In Ethiopia, N. sativa is often practiced intercropped with barley and wheat (Ahmed and Haque, 1986).

\subsection{Pollination}

Flowering is protandrous and pollination is believed to be mainly by insects. In older flowers the stigmas bend down and self-pollination may occur (Animesh, et al 2012).

\subsection{Climate Requirement of Black Cumin}

Climate and soil conditions that are the main factors on growth and development of black cumin, the physiological growth of the plant, being synthesized of the active substances, the amount and quality of obtained essential oil. Especially, the effect of ecological factors on yield and essential oil of medicinal plants is higher compared to the other plants. Because the quality in medicinal and aromatic plants is as important as yield, the ones below a certain quality cannot be cultivated even if they are very high yield. Therefore, they should only be cultivated in the convenient regions for the ecologies of these plants (Yasar, 2005).

In Ethiopia, it is cultivated as a rain fed crop in the highlands at $1500-2500 \mathrm{~m}$ altitude with annual rain fall of $120-400 \mathrm{~mm}$ and average temperature of $12-20{ }^{\circ} \mathrm{C}$ is very suitable for optimum flowering, pollination and fruit setting of this spice. It is successfully grown in most kinds of soil with $\mathrm{pH} 5-8$ (Takruri and Dameh, 1998). Even though Black cumin described as hardy crop growing on all kinds of soils (Jansen, 1981) Sandy loam soil rich in microbial activity is the most suitable for its cultivation. The sloppy soils of heavy rainfall areas and leveled and well drained soils of moderate rainfall areas are 
quite suitable for its cultivation (Orgut, 2007). But in Ethiopia grown on heavy black soils which have a similar ecological requirement as teff chick pea and lentil, (Adam, 2007)

In Ethiopia, black cumin is cultivated in south Wollo, South Gonder, in Amhara Region; North Shoa. West shoa, Arsi Bale, Jimma Illubabor Zones in Oromya region and Benchi Maji, Keffa and Sheka in SNNP within 'Woina Dega' dry areas (MoARD, 2003)

\subsection{Land Preparation}

Black cumin is low volume and high value crop and can be a good rotation crop for cereals and pulses. In Denbia, it is a rotation crop for chick pea and teff, (Adam, 2007). It requires well prepared land ploughed at least 3 times, (Ermias et al., 2015) followed by 2-3 harrowing and leveling (Ebrie, 2015) and the soil should be fine, light, and free of logging, loam and with enough nutrient composition which can be improved by fertilizer application.

\subsection{Spacing}

The recommended seed rate of black cumin is $15-20 \mathrm{~kg} /$ ha for broadcasting while for drilling $5-7.5$ $\mathrm{kg} / \mathrm{ha}$. Seed is direct sown on permanent field since seedlings are too fragile for transplanting, but seed may also be sown in peat blocks. A row spacing of $15-40 \mathrm{~cm}$ is common. In Ethiopia, N. sativa is often intercropped with barley and wheat (Ahmed and Haque, 1986).

\subsection{Fertilizer Recommendation}

The maximum total yield $6416.7 \mathrm{~kg}$ ha, obtained from the interaction effect of $60 / 40 \mathrm{~kg} \mathrm{NP}$ ha. The highest seed Yield (1336.7 kg ha was obtained from 60/40 kg N P ha, (Yimam et al, 2015).

\section{Propagation and Planting}

\subsection{Sowing Time}

Black cumin is propagated by seed. The sowing time varies as a function of the local environmental conditions. Sowing can be conducted in a rainy season from August up to September and also it will sown by irrigation from April to May. The recommended seed rate is 5 to $7.5 \mathrm{~kg} / \mathrm{ha}$ (Girma, 2015) at the depth of $2 \mathrm{~cm}$. Its germination is epigeal and takes 10-15 days, in temperate climates. After 20 days of sowing thinning of the plants to a distance of $20 \mathrm{~cm}$ is recommended. Starts flowering about 100 days after sowing and seed reaches maturity 50 days later. In warmer climates, flowering may start 810 weeks after germination. Germination is promoted by darkness and high temperatures. Germination in darkness represents the highest rate $(41.32 \%)$. It decreases thereafter according to light exposure. It is almost zero at 18 hour of light exposure. This shows that darkness was a key factor for the germination of Nigella sativa. A maximum rate of germination which is $41.32 \%$ at $20^{\circ} \mathrm{C}$, in distilled water and in darkness was recorded while, temperature below $10^{\circ} \mathrm{C}$ and above $25^{\circ} \mathrm{C}$, rates of germination were very low with respectively only $4 \%$ and $2 \%$. Maximum rate of germination was observed at $20^{\circ} \mathrm{C}$ with 20.7 seeds that corresponds to $41.40 \%$, (Abdullah, 2017).

\subsection{Pathology of Black Cumin}

\subsubsection{Weed Control}

Black cumin is affected by weed especially in the emergency stage. Frequent weeding reduces weed competition and produce good environmental condition for growth and development. About 3-5 weeding at an interval of 20 to 25 days is recommended by hand hoe.

Wilt (Fusarium oxysporum or F. cumini): The disease can attack the plants at any stage. The infected plants leaves and branches becomes light green in colour, leaves shed and plants dries up and die. Since the infection occurs in the roots it is very difficult to control this disease and it inflicts heavy losses in all the cumin-growing areas.

The following measures may help in controlling wilt disease: (i) use healthy and clean seeds; (ii) seeds should be treated with pesticides like fungicide Bavistin, Captan, Thirarn $2 \mathrm{~g} / \mathrm{kg}$ of seed before sowing, (iii) follow crop rotation; and (iv) deep summer ploughing is also recommended to keep the infection.

Wilt: (causal organism grows along the seedling; therefore, we can control: by spraying Dithane M-45 $0.2 \%$ or Dithane Z-78 or Blitox 5 w.p. at 15 days interval) and rotting of bulbs (emit a special odour; control: dipping bulbs in $0.3 \%$ bavistin for 30 mins. before planting, field kept free from stagnant water) 
are diseases reported. Early report by McRae and Shaw also suggested (Animesh, 2012) Fusarium wilt in the species.

\subsection{Common Insect Pests Recorded}

- Caterpillar - Makes holes in the bulbs and cut down seedlings. We can Control: Dust the soil at the sowing or hoeing with 5\% Aldrine, $10 \% \mathrm{BHC}$ at the rate of $25 \mathrm{~kg}$ per hectare; application of well-decomposed farmyard manure.

- Armyworm and semi-looper - Feed on the flowers, seeds, and damage the crop.

Control: Spray with $0.05 \%$ methyl parathion $-1 \mathrm{ml} / 1$ water or Thiodian or Endosal 35EC, $1 \mathrm{ml} / \mathrm{l}$ of water at 15 days interval, (Animesh, 2012).

\subsection{Harvesting and Handling}

Identifying the appropriate stage of maturity for harvest, together with most effective and best techniques of harvesting, drying, and processing of the produce is essential. The crop harvested before shedding at little green stage gives high aromatic oil contents providing good market. Black cumin retains seed viability longer when it is fully ripe. It is rather essential that harvesting is done before shedding (shattering of fruits is a major problem) and therefore 2 to 3 or more pickings can be done to avoid loss of seeds due to shattering of the capsules. The harvested crop is dried under sun and threshed by beating with the stick, (Animesh, 2012)

The seeds of $N$. sativa can be removed by light threshing. They must be stored under dry conditions to maintain their characteristic spicy flavour. Under normal dry room conditions, seed remains viable for 2-3 years. Broken seeds deteriorate rapidly, due to the activity of lipases.

\subsection{Shelf Life}

The seeds of $N$. sativa store well for one year as planting material and as a spice, they are stored in airtight conditions to prevent the loss of aroma. As a spice, it is recommended to be stored away from other species as the species has an overbearing flavour and aroma and disturb the flavour of other species (Animesh, 2012).

\subsection{Production Status}

Even though black cumin has a long history in Ethiopia it's production increasing not only for its spice value but also as medicinal value in Ethiopia and also the world. According to MoA in Ethiopia produced in the year 2012, 9533 ton/cumin with in 5336 ha of land in a fragmented area of small scale farmer's field. That is why its production is lower and less significant when we compare other producing countries, (MoA, 2012)

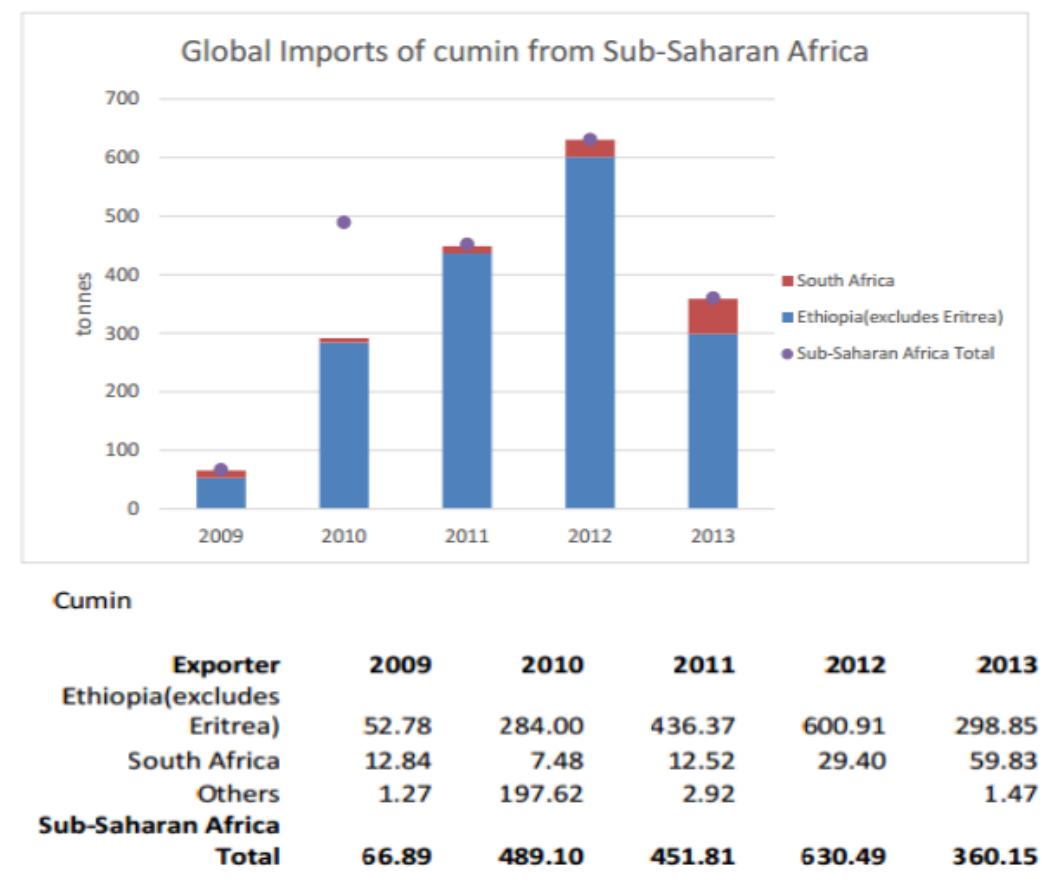


The production and land coverage of black cumin has now increasing, but the productivity is still less than $0.64 \mathrm{t} \mathrm{ha}^{-1}$ (EIAR, MoA, FAO, 2014). But according to some researchers with good managements they have produced 1.5 t/ha (Girma et al., 2008, NVRC, 2005, 2006, 2007, 2008, 2012, 2013 and 2014); High seed yields of up to $1716.15 \mathrm{~kg}$ ha-1 at Adet and $1869.56 \mathrm{k}$ ha- 1 at Woreta were obtained (Adam, 2006) this is also very low when we compare other countries like India $2.2 \mathrm{t} / \mathrm{ha}$. These is mainly due to the uses of low yielding genotypes, the released varieties (Dirishaye, Eden, and Deribera) are less productive than local checks in SWE, (Ermias et al., 2015), poor crop management practices, high weed incidence, disease (wilt disease), insect damage, inadequate planting density, lack of knowhow on postharvest handling, marketing system and lack of nutritional processing techniques, etc. are accountable for low productivity and production of black cumin, (Yosef, 2008).

\section{RESULTS AND DISCUSSION}

\subsection{Research Achievements on Ethiopian Black Cumin}

Ethiopia is a land of diverse climate and soil types that enable prolific growth of several indigenous and exotic spices, herbs, medicinal and other essential oil bearing plants. Despite availability of the diverse agro-ecologies of the country to produce these huge number of black cumin genotypes which playing a significant economic role on the national economy through generating considerable export earnings or import substitution, the research conducted on this spice is very limited due to various reasons.

Currently, Lowland spices and highland seed spices were given special research attention (Girma et al, 2015). Among these spice crops like korarima (Aframomum corrorima), black pepper (piper nigrum L.), ginger (Zingibere officinale Rosc.), cardamom (Ellettaria cardamomum), turmeric (Curcuma domestica), cinnamon (Cinnamomum verum), vanilla (Vannila fragrance), black cumin (Nigella sativa), coriander (Coriandrum sativum), fenugreek (Trigonellafoenum-graecum L.), etc.

There are some research's conducted to improve black cumin production in Ethiopia. Among those conducted researches; twenty eight local accessions and two introductions of black cumin were evaluated to assess their genetic variability and to determine their essential oils and fatty oil contents at Adet and Woreta, (Abebe, 2006).

From these varieties Eden was introduced from Yemen Arab Republic while Dershaye was obtained from the Institute of Biodiversity Conservation with passport number of 223072. In 2004 black cumin preliminary observation nursery was initiated at Wondo Genet by the oilseeds and spices team. The observation included 42 accessions obtained from the Institute of Biodiversity Conservation. The 42 accessions and two introduced lines were characterized for agronomic and quality traits. During the offseason of 2005/06, promising accessions were mass selected for high seed yield and quality. During the main season of 2005/06 yield testing was carried out at Adet and Woreta in the Amhara Region. In 2006/07 yield testing was carried out at Jimma, Bonga, Kulumsa and Adet.

Darbera, Eden and Dershaye, (NVRC, 2012, 2013, and 2014) had been released and supplied for users but not widely distributed yet. More of these released and/or registered varieties had been proved highly promising giving high yield as well as quality standards in international market

Both Dershaye and Eden require 134 to 150 days from planting to full maturity. Both varieties reach a height of 54-64 cm at maturity. Although, both varieties have equal number of primary branches per plant (2-4), Dershaye has more secondary branches per plant that bear more pods and hence higher seed yield. The two varieties have higher seed yield, oleoresin and essential oil contents in the seed.

Eden has fatty oil of 37 to $41 \%$, essential oil of $0.6-1.2 \%$ and oleoresin of 27.2 to $32.4 \%$. Dershaye has fatty oil of 36 to $41 \%$, essential oil of $0.7-1.3 \%$ and oleoresin of $30.8 \%$. The fatty oil from black cumin is not used for cooking due to its nigellon content that causes bitter taste of the oil. Dershaye and Aden were developed by the former Essential Oils Research Center and registered by the Ministry of Agriculture and Rural development, Animal and Plant Health Regulatory Directorate in 2009, (Adam, 2007).

- Molecular diversity study of 84 black cumin (Nigella sativa L.) accessions were done from Ethiopia as revealed by inter simple sequence repeat (ISSR) markers that are collected from IBC at Genetics, laboratory Department of Microbial, Cellular and Molecular Biology, Addis Ababa University (Birhanu, 2015).

- Correlation Studies in Yield and Some Yield Components of Black Cumin (Nigella sativa L.) Landraces Evaluated at Southeastern Ethiopia (Fufa, 2016). 
Acquiring sufficient types and number of germplasm is the corner stone to achieve the desired goals of improvement in any crop species. Thus it is imperative to give peculiar attention to this aspect to succeed in the endeavor. In that, evaluation and identification of the best performing species and/or varieties that could serve as the best alternatives for black cumin diversification in various agro ecologies of the country was the major goal set by the national spices research. Consequently, 175 black cumin accessions (un published data from IBC, 2017) from highland seed spices were collected and/or introduced from different corners of the country and among them some of evaluated under some agro ecologic conditions of the area. In the course of this evaluation, strong emphasis was given to their performance in adaptation measured by their vegetative performance, yield, quality and oil content. Concomitantly, the research findings for highland seed spices were very promising in more of the cereal-based farming system of mid-altitude and highlands of Ethiopia.

Knowledge about plant genetic resources enable plant breeders to create novel plant gene combinations and select crop varieties more suited to the needs of diverse agricultural systems (Glaszmann et al., 2010). Estimation of genetic diversity in black cumin is essential for breeding programs and for the conservation of its genetic resources.

For any crop improvement program, a breeder depends on the variability present in the germplasm collected in order to advance in production, bring about stability in different biotic and abiotic stresses or changes in crop characteristics and meet breeding interest (Ibrahim et al., 2010). Therefore, highly promising varieties of black cumin, coriander and fenugreek for highland seed spices had been identified based on their adaptation, yield, extraction quality and chemical composition that could meet the international standards, provided they are produced following appropriate agronomic and postharvest handling techniques.

\subsection{Research Gaps}

- Best from black cumin accessions that are highly adaptable and productive under the specific agro ecologies were not identified well. Due to this further researches must be conducted to identify the best alternative adaptive, productive and promising genotypes for all growing area in Ethiopia

- Researchers require special exposure to post harvest technologies elsewhere. Studies on crop protection and soil nutrition are the other areas of research that had not been given full research coverage on black cumin.

- It is also very necessary to establish up-to-date laboratories to run quality evaluations. Shortage of planting material had also been a crucial bottleneck for wider dissemination of these crop species to farmers.

- Giving a prime attention to market promotion for these low-volume high-value crop species has also been essential.

- There is no enough information or research result about integrated pest management techniques for black cumin.

- There is a serious gap in demonstration and popularization of available technologies of this valuable crop of economic significance. Emerging issues such as wilt that devastated black cumin production should be given a prime attention.

- Further study is needed with more samples from entire regions of Ethiopia to assess the extent of genetic diversity of Black cumin.

- More collection missions are needed to increase the number of Black cumin germplasm accessions at the National gene bank.

- One of the important factors restricting their large-scale production and development of better varieties is that very little information is available about their genetic diversity, inter and intraspecific variability and genetic relationships among collected accessions at IBC Ethiopia. Therefore, attempts to analyze possible untapped genetic diversity become extremely essential for breeding and crop improvement

- In Ethiopia, it is not commonly cultivated using separate farm plot rather planted along with different boarder crop. That means value chain analysis of black cumin is not done to boost producers interest for growing on a sole crop on a given field. 


\subsection{Future Prospects}

- Conducive environmental condition and promising varieties of highland spices had been identified and released for users. Therefore, it is a very good opportunity to multiply and disseminate the available technologies within the recommended agro-ecologies of the country.

- The widespread use of N. sativa in oriental cooking and in traditional medicine ensures future interest in the crop.

- The current interest in herbal medicine, together with the interest being shown in the crop by the pharmaceutical industry may boost the importance of $\mathrm{N}$. sativa.

- Currently, in some parts of the world, there is a renaissance of interest in traditional remedies. Many investigators now believe that traditional medicine is a promising source of new therapeutics against cancer (Ahmad, 2013). Towards the end of the 20th century, plant based products, neutraceuticals and food supplements comprising the complementary and alternative therapie s have gained a big share in the drug market in the developed countries this indicates the big indicator to boost black cumin demand.

- The government policy also supports and gave priority for agricultural production.

- Processing black cumin essential oil industrially is very limited. Producing back cumin oil industrially results in a quality product and will be a source of income by exporting it to other countries. A large amount of black cumin seed now a day is exported to Middle Eastern countries. Instead of exporting the seed, exporting the oil will bring more income and evaluation of oil yield in all accessions collected is very essential.

\section{CONCLUSiON}

Nigella sativa L. (commonly known as black cumin) belongs to family Rannunculaceae, which is an important medicinal plant with worldwide distribution. It is one of the most important spices crop in the world including Ethiopia. This spice is used to successfully keep people super healthy for over long years. It is one of the earliest cultivated plants in human history, which means it was one of the early providers of life. The miracle seed has been used by millions of people to treat various ailments for centuries in different parts of world because it contains essential macro and micronutrients which play vital roles as structural and functional components of metalloproteins and enzymes in the living cells.

Ethiopia has diverse agro ecologies which can grow varieties of spice crops but due to various reasons which cannot succeed to get the required standard due to lack of awareness about black cumin value and production managements and also due low attention given for spice crops.

Researches conducted on black cumin is not enough rather it remained back to compute with other producing country like India. As like I mentioned on research Gaps we should give higher attention for achieving our goal.

\section{REFERENCES}

[1] Abdullah S. Alshammari, 2017. Light, salinity and temperature effects on the seed germination of Nigella sativa L. College of Science, Biology department, Hail University, Saudi Arabia Global Journal of Biology, Agriculture and Health sciences. 6 (1):25-31.

[2] Abebe, Adam; Alemaw, Getinet; W/Tsadik, Kebede, 2006. Evaluation of Ethiopian Black Cumin (Nigella sativa L.) Landraces for Agronomic Characters and Oil Content at Adet and Woreta, North West Ethiopia.

[3] Adam Abebe, Getinet Alemaw and Kebede Wolde Tsadik, 2007. Agronomic characteristics and oil contents in black cumin (Nigella sativa L.). Eth. J. Agric. Sci. 19(1/2):1-16.

[4] Ahmad A, Husain A, Mujeeb M, et al [2013)] A review on therapeutic potential of Nigella sativa : a miracle herb. Asian Pac J Trop Biomed 3, 337-52.

[5] Ahmed, N.U. and Haque, K.R. 1986. Effect of row spacing and time of sowing on the yield of black cumin (Nigella sativa). Bangladish Journal of Agriculture, 11, pp. 21-24.

[6] Animesh K. Datta, Aditi Saha, Arnab Bhattacharya, Aninda Mandal, Rita Paul and Sonali Sengupta, 2012. A Review on black cumin Nigella Sativa L.). Department of Botany, Cytogenetics and Plant Breeding Section, Kalyani University, Kalyani 741235, West Bengal, India

[7] Ansari, T.M., Ikram, N., Najam-ul-Haq, M., Fayyaz, I., Ghafoor, I. and Khalid, N. 2004. Essential trace metal (Zinc, Manganese, Copper and Iron) levels in plants of medicinal importance. J. Biol. Sci. 4, pp. 95-99. 
[8] Assefa Ermias, Addis Alemayehu and Teshom Mamo, 2015. Adaptability Study of Black Cumin (Nigella sativa L.) Varieties in the Mid and High Land Areas of Kaffa Zone, South West Ethiopia. Agriculture, Forestry and Fisheries. 4, No. 1, pp. 14-17.

[9] Azeez, S, (2008) cumin. In: Parthasarathy, V.A., Champakamam, B. and Zachariah, aT.J., eds: Chemistry of spieces. CABI International, Wallingford, UK.

[10] Birhanu Kapital, Tileye Feyissa, Yohannes Petros and Said Mohammed, 2015. Molecular diversity study of black cumin (Nigella sativa L.) from Ethiopia as revealed by inter simple sequence repeat (ISSR) markers African Journal of Biotechnology. 14(18), pp. 1543-1551, 6 May, 2015

[11] Ebrie Yimam, Amsalu Nebiyu, Ali Mohammed and Merkebu Getachew, 2015. Effect of Nitrogen and Phosphorus Fertilizers on Growth, Yield and Yield Components of Black Cumin (Nigella sativa L.) at Konta District, Southwest Ethiopia.

[12] Ethiopian Investment Agency, (2015). Investment opportunity Profile for Spice Processing in Ethiopia. 7:8-14.

[13] Fufa M (2016). Correlation Studies in Yield and Some Yield Components of Black Cumin (Nigella sativa L.) Landraces Evaluated at Southeastern Ethiopia. Adv Crop Sci Tech 4: 239.

[14] Ghaznavi KM, (1991). Tibbe-e-Nabvi aur Jadid Science, Al-Faisal Nasheeran wa Tajeera-e- Kutab. Urdu Bazar Lahore, Pakistan. 1:228-236.

[15] Girma H, Digafie T, Edossa E, Belay YB, Weyessa G (2008). Spices research achievements, revised edition, Ethiopian Institute of Agricultural Research, Addis Ababa Ethiopia, pp 7-25.

[16] Girma Hailemichael Habtewold Kifelew and Haimanot Mitiku, 2015 Spices Research Achievements, Challenges and Future Prospects in Ethiopia. Academic Research Journal of Agricultural Science and Research. 4(1), pp. 9-17, January 2016.

[17] Glaszmann, J.C.,Kilian, B.U., padhyaya, H.D., and Varsheney, R.K.2010. Accessing geneticdiversity for crop improvement Science direct Current opinion in plant biology. 13, pp. 167-173

[18] Goreja W (2003). Black Seed: Nature's Miracle Remedy, New book provides a comprehensive overview of the science behind the miracle of Black Seed and details recent studies and modern uses.

[19] Iqbal, M.S., Ghafoor, A. and Qureshi, A.S. 2010. Evaluation of Nigella sativa L. for genetic variation and ex-situ conservation. PakJ Bot. 42, pp. 2489-2495.

[20] Jansen, P.C.M., 1981. Spice, condiments and medicinal plants in Ethiopia, their taxonomy and agricultural significance. Center for Agricultural Publishing and Documentation, the Netherlands 294p. Market Insider/ITC 2014

[21] MoARD, Ministry of Agriculture and Rural Development, 2003. Development of black cumin and white Cumin Production. 25p.

[22] National Variety Registry Committee NVRC (2005, 2006, Hailemichael et al. 2007, 2008, 2012, 2013, 2014). National Crop Variety Register. Animal and Plant Health Regulatory Directorate, Ministry of Agriculture and Rural Development, Addis Ababa Ethiopia.

[23] Orgut, 2007. Market Assessment Study, Ethiopian Nile Irrigation and Drainage Project, Main Report and Annexes, Ministry Of Water Resources, Addis Ababa.

[24] Ramadan, M.F and Morsel, J.T, 2003. Analysis of glycolipids from black cumin (Nigella sativa L.), coriander (Coriandrum sativum L.) and Niger (Guizotia abyssinica cass.) oil seeds. Food Chem. 80, pp. 197-204.

[25] Spice, Herbs and aromatic plants sub sector plat form the first stakeholders meeting Addis Ababa, Ethiopia, January 23, 2014.

[26] Takruri, H.R.H. and Dameh, M.A.F. 1998. Study of the nutritional value of black cumin (Nigella sativa L.). J. Sci. Food Agric. 76, pp. 404-410.

[27] Warrier PK, Nambiar VPK, and Ramankutty. 2004. Indian medicinal plants-a compendium of 500 species. Chennai Orient Longman Pvt Ltd; 139-142.

[28] Weiss, E.A. 2002. Spice Crops. CABI Publishing.CABI International, Wallingford, Oxon, UK.

[29] Yasar, S. 2005. Determination of fixed and essential oil contents and soil characteristic of some perennial medical plants that grow naturally in the campus of Cukurova University. Department of Biology Institute of Natural and Applied Sciences University of Cukurova. MSc Thesis, 43p, Adana. (in Turkish).

[30] Yilmaz, G. 2008. New approaches in growing of medicinal and aromatic plants. Graduate Course Notes (unpublished). Gaziosmanpasa University Agriculture Faculty, Field Crops, Tokat. (in Turkish). 
[31] Yimer Masresha, 2010. Market profile on spices: Addis Ababa, Ethiopia. P - 22

[32] Yosef, H.H., 2008. Effect of high levels of nitrogen and phosphorus fertilizer on growth, yield and yield components of Nigella sativa L. Horticulture Department College of Agriculture, Duhok University, Iraq, Mesopotamia Journal Agriculture.

Citation: Zigyalew Gashaw, "Status of Black Cumin (Nigella Sativa L.) Research and Production in Ethiopia; A Review,", International Journal of Forestry and Horticulture, 6(3), pp. 20-29. DOI: https:// doi.org/10.20431/2454-9487.0603003

Copyright: (C) 2020 Authors, this is an open-access article distributed under the terms of the Creative Commons Attribution License, which permits unrestricted use, distribution, and reproduction in any medium, provided the original author and source are credited. 